information is desirable, and that recommendations to this end should be put forward.

The report submitted by the Committee of Experts as to species recommended for inclusion in the Annex of the Convention on the occasion of its next revision was accepted. This contained proposals for the transference of certain species mentioned in the Annex from Class $B$ to Class $A$, thereby affording them greater protection, and included among others the giant eland (Taurotragus derbianus (Gray)), black rhinoceros (Rhinoceros bicornis Linnæus) and secretary bird (Sagittarius serpentarius serpentarius Miller). The report also suggested the inclusion in both classes of certain species not heretofore included in the Annex. For inclusion in Class $A$ were recommended among others the red wolf (Canis simensis (Ruppell)) and bongo (Boocercus eurycerus Ogilby) and the African peacock (Afropava congensis Chapin), so recently discovered to science, northern secretary bird (Sagittarius serpentarius gambiensus Ogilby), African broadbill (Pseudocalyptomena graueri Rothschild), Abysinnian ground chough (Zavattariornis stresemanni Holtoni), the flightless rail of Inaccessible Island (Atlantisia rogersi Lowe) and the so-called fishes of the grottoes of Thysville, African species of the genus Caccobarbus. The last-named was the only case for the protection of fish brought to the attention of the Committee. The species being blind and of great zoological interest, it is the opinion of the Committee that it should receive as complete protection as possible.

The Conference agreed to recommend that a further meeting be held in London in 1939, concurrently with the meeting of the proposed International Conference for the Protection of Fauna and Flora of Tropical Asia and the Western Pacific. On the proposal of Mr. te Water, it was agreed to express the hope that it would be possible for the Governments concerned to arrange for the attachment to their respective delegations of officers in charge of the principal national parks, such as the Kruger National Park, and the Parc National Albert, whose expert advice would greatly assist the work of the Conference.

\title{
Impact of Chemistry on Biology
}

$\mathrm{T}$ HE forty-second Bedson Lecture was delivered in the Chemistry Lecture Theatre, King's College, Newcastle-on-Tyne, on May 19 by Sir Henry Dale, who spoke on "The Impact of Chemistry on Biological Science". Sir Henry pointed out that the two sciences of biology and chemistry were developed during the nineteenth century independently of each other; tremendous advances have been made in more recent times as the two subjects have become closely interwoven into the science of biochemistry.

Since the end of the last century, organic chemistry has developed along two main lines: (1) the synthesis of new substances of little direct relation to biological science, and (2) the isolation and identification of substances from 'vital' chemistry. Progress has been slow in the chemistry of the animal body, and the lag between chemical recognition and the assignment of a definite biological function to compounds isolated is well exemplified by the fact that although creatine was isolated from muscle in 1832, it was not until 1927 that a definite role in muscle metabolism was assigned to this substance.

The comparatively new science of bacteriology had its origin in the work of Louis Pasteur, an organic chemist whose interests developed along 'biochemical' lines until he eventually became a complete biologist.
The investigation of protein chemistry by Sir Frederick Gowland Hopkins which led to his attempt to make a 'perfect' diet by mixing the correct amounts of fats, carbohydrates and proteins gave rise to one of the most sensational discoveries in recent years, the vitamins. In a very short time, many of these compounds have been not only isolated, but also in some cases have been assigned a definite chemical formula which has been proved by synthesis.

Several enzyme actions have recently been in. vestigated from a chemical point of view, and it seems extremely probable that enzyme and coenzyme phenomena will shortly be explained as chemical actions, closely.connected in some cases with the vitamins.

The discovery of the natural stimulants formed by the animal body, the hormones, has opened up an important new field of biochemical research, in which great advances have already been made. Several of these compounds have been isolated and synthesized, such as, for example, thyroxin and adrenaline, and the sex hormones have been shown by synthesis to be closely connected with inert sterols present in animal tissues.

Finally, even the transmission of nerve 'messages' has been shown to involve reversible physicochemical changes in which simple organic compounds play a part.

\section{Pre-Roman Provence}

$\mathrm{E}^{\mathrm{A}}$ ARLY in April of this year, it was announced that archæological discoveries, which are of no little importance, had been made near Saint-Rémy, a small town a few miles from Arles in Provence. Provence, the original 'Provincia' of Rome's extraItalian expansion, is rich in monuments, which, if Roman in origin, are none the less Greek in spirit and conception. This is a legacy from the Greek colonists from Phocaea, who founded Marseilles about 600 B.c. and extended their influence over the whole region, which was later to be known as "The Province". Intermarriage with the natives left an indelible mark on the physique of the population, more especially to be seen in the beauty of the Provençal women.

Although the district around Arles was termed "Grecia" until the fourteenth century, little is known that is of purely Greek culture, nor has it been determined with precision how far and to what degree Greek influence pervaded the country. The importance 
of the results of recent excavations lies in the fact that they have brought to light remains belonging to the pre-Roman period, as well as evidence pointing to the measure of fusion with native culture.

At Saint-Rémy, which possesses two theatres of the Roman period, both Greek and Roman constructions beside a tile-covered canal have been found near a Roman road, triumphal arch and tomb dating from the first century, and beneath a Roman wall. Fifty-two altars of local stone and marble were dedicated to either the god Sylvanus or the goddess Cybele. The foundations of an entirely Greek house were uncovered, in which twelve rooms are seen to have opened into an atrium, in which the bases of four columns are still visible. Baths of the time of Augustus, measuring forty-seven yards by thirty-five yards, were found. Into these, water flowed through a huge sculptured head. A large amount of Greek red-on-black pottery was found with forty-four small votive lamps and a magnificent rock crystal ring, ornamented with a woman's head.

Further discoveries in these excavations are now announced. According to a dispatch from the Paris correspondent of The Times in the issue of May 23, while most of the walls which have been found belong to a large Roman construction, the architectural remains of pre-Roman date are also important. A pillar with egg and astragalus pattern is of secondcentury Greek style, while column heads, probably pointing to Italian models, are evidently the work of competent masons of Greek training. The gargoyles, however, are the rustic Celtic versions of classical gargoyle lions. It is thought that they belong to a building, possibly a temple, of Greco-Celtic style.

Further evidence of cultural fusion comes from Glanom, a small Celtic oppidum near Saint-Rémy, where in a large necropolis graves containing Celtic and local Hellenistic pottery have been excavated by M. de Brun, keeper of the local museum. The tombs, it is stated, are marked by tall pillars, on which Celtic names are inscribed in Greek character. The cemetery is dated in the period of the Roman occupation at the end of the second century B.c. Still earlier evidence comes from Roquepertuse, where the Count de Gerin-Ricard, keeper of the Musée Borely at Marseilles, has excavated a sanctuary of the fourth century B.c. Here he has found what is described as a curious mixture of native and Greek taste. The pillars supporting the entablature are decorated with the heads of slain enemies, the horses on the frieze are of the barbarian type, while the double heads affixed to the architrave are a successful and attractive blend of Celtic and Greek elements.

\section{Antarctic Plankton*}

$\mathrm{E}^{\mathrm{x}}$ ACT systematic work is essential for oceanographical plankton studies, since we must know the species with which we are dealing before we can use them in any practical way. Mr. Hendey's extensive monograph on the diatoms of the Southern Ocean is most useful and is a careful study entailing a large amount of labour. With so much material it has been possible to review the inside variation present in most groups and in the individual species. The interesting fact is clearly brought out, agreeing with Wimpenny (1936) that the diatom frustules in cold water are smaller, thicker-walled and more vigorous than those from warmer waters, the reverse of what is known to exist in many marine animals. The holoplanktonic flora of the cold water from the oceanic habitats forms the major part of the collection and consists of a small number of discoid and a large number of filamentous pennate forms. The author, however, in his classification discards the usual division into Centricæ and Pennatæ, and his method of regarding many so-called species and varieties as "phases" of one species reduces considerably the number of species recognized. Thus, to take one example, Corethron according to Hendley is a monotypic genus, Corethron criophilium, mich discussed by many workers, being the only species with many phases. This at least tends to simplify matters, and a reduction of the ever-increasing number of species is all to the good.

Most of the diatoms of the Southern Ocean have

* Discovery Reports. Issued by the Discovery Committee, Colonial office, London, on behalf of the Government of the Dependencies of the Falkland Islands. Vol. 16. Pp. 151-364 + plates 6-13. The Plankton Diatoms of the Southern Seas. By N. Ingram Hendey. 33s. net. Vol. 16. Pp. 365-412. The Seasonal Circulation of the Antarctic Macroplankton. By N. A. Mackintosh. 6s, net. Vol. 16. Pp. 413-446+plate 14. Rhizosolenia curvata Zacharias. By Dr. T. John Hart. 58. net. (Cambridge: University Press, 1937.) a wide distribution and can tolerate a great variation in the conditions of their environment, but it is found that Rhizosolenia curvata Zacharias has a very limited range, being a typical sub-antarctic species occasionally spreading into Antarctic waters. Dr. Hart in his paper on this diatom shows that it forms a valuable indicator of the southern limit of subantarctic surface water. It has always been recognized that this surface water is frequently forced some small distance south of its normal limit, the Antarctic Convergence, and it has been possible to prove that $R$. curvata, an easily recognizable and characteristic form, is always in the plankton whenever it has been possible to show such southward movement hydrographically.

The seasonal circulation of the Antarctic macroplankton is dealt with by Dr. Mackintosh. Amongst other interesting facts it is shown that certain species which are usually regarded as inhabitants of the surface layers make an annual vertical migration into deep water in winter, and this migration by which they move from one current system to another is probably the means by which they keep within their normal ge ographical boundaries. The three species which in places make up the bulk of the Antarctic macroplankton, Rhincalanus gigas, Eukrohnia hamata and Calanus acutus, are mainly concentrated in the surface water in summer but descend into very deep water in winter. Since part of the Antarctic surface water moves in a northerly direction and there is a compensating southerly movement of the warm deep water, this vertical migration almost certainly results in the return of the species to the regions from which it originally came. The circulation is on a very large scale, the vertical range being from four to six hundred metres and the horizontal range being presumably some hundreds of miles. 